\title{
KARAKTERISASI ES KRIM EDAMAME DENGAN VARIASI JENIS DAN JUMLAH PENSTABIL
}

\author{
Characterization of Edamame Ice Cream Produced Under Different Type and Amount of \\ Stabilizer
}

\author{
Kamalia Istiqomah $^{1)}$, Wiwik Siti Windrati ${ }^{1)}$, Yhulia Praptiningsih ${ }^{1) *}$ \\ ${ }^{1)}$ Jurusan Teknologi Hasil Pertanian - Fakultas Teknologi Pertanian, Universitas Jember \\ Jalan Kalimantan 37, Kampus Tegal Boto Jember 68121 \\ *E-mail: yhulia.ftp@unej.ac.id
}

\begin{abstract}
Ice cream is a frozen dessert usually made from dairy products such as milk and often combined with other ingredients which made by freezing and agitation. Edamame can be make to vegetable milk as raw material of ice cream. The production of ice cream need stabilizer to get the good properties of ice cream. The purpose of this research were determine the type and amout of stabilizer to produce the good properties and preference of ice cream. This research conducted by Completely randomized design (CRD) with two factor. The first factor were types of stabilizer (carragenan and $C M C$ ) and the second factor were amount of stabilizer $(0,2 \% ; 0,4 \% ; 0,6 \%)$. The parameter observation were overrun, brightness, melting rate, textur, and preference colour, taste, flavor, texture and overall of ice cream. The best tratment was determined by effectiveness test. The best result was obtained on ice cream with stabililizer CMC 0,4\%. The ice cream had overrun $24,51 \%$, brightness 80,30 , melting rate 38,01\%/15 minute and texture $11,7 \mathrm{~mm} / 10$ seconds and the preference value of colour 4,08 (rather like to like); flavour 4,60(netral up to rather like); taste 6,05 (like to very like); texture 6,12 (like to very like); overall 5,84 (rather like to like) .
\end{abstract}

Keywords: carrageenan ice cream, edamame, stabilizer, CMC

\section{PENDAHULUAN}

Edamame sebagai bahan hasil pertanian yang dikenal dengan kedelai jenis sayur atau soy vegetable merupakan kedelai varietas Jepang yang dapat ditemui di daerah Jember (Jawa Timur), Cipanas dan Ciawi-Bogor (Jawa Barat). Daerah-daerah tersebut merupakan daerah yang mengembangkan edamame yang berada di pulau Jawa (Khaeruni, 2008). Adanya kedelai jenis edamamae di Jember menjadikan Jember memiliki komoditas unggulan yang telah diakui dunia, hal tersebut dapat dibuktikan bahwa PT Mitra Tani 27 Jember dipercaya untuk mengekspor edamame ke Jepang, China, Taiwan, Vietnam, dan Thailand dengan jumlah permintaan kurang lebih mencapai $5.000-10.000$ ton per tahun (Kurniasanti, 2014). Namun, untuk edamame yang tidak lolos strandar ekspor (edamame afkir) jumlahnya masih banyak yaitu 52,43\% (Yordanio, 2015). Edamame afkir tersebut dipasarkan di daerah lokal dengan harga yang sangat rendah. Edamame afkir masih memiliki kandungan nutrisi yang sama dengan edamame pada umunya. Edamame mengandung protein $11,4 \%$, lemak $6,6 \%$ (Muaris, 2013). Untuk meningkatkan nilai guna dari edamame maka dimungkinkan edamame diolah menjadi es krim sebagai pengganti bahan utama susu.

Penggantian susu hewani dengan susu nabati dalam pengolahan es krim dapat mempengaruhi karakteristik es krim. Penggunaan penstabil dalam pembuatan es krim diperlukan untuk memperbaiki mutu es krim. Fungsi dari penstabil yaitu untuk mempertahankan stabilitas emulsi, mencegah pembentukan kristal es yang besar, menurunkan kecepatan meleleh serta memperbaiki tekstur, dengan adanya 
bahan penstabil menjadikan es krim lebih halus dan lembut (Susrini, 2003). Beberapa bahan penstabil yang dapat digunakan dalam pembuatan es krim CMC (carboxymethil cellulose), gelatin, Naalginat, karagenan, gum arab dan pektin (Darma et al., 2013). Dari banyaknya jenis penstabil tersebut, penstabil yang cukup ekonomis yaitu CMC dan karagenan. Kelebihan CMC mampu mengikat air dalam kapasitas yang besar, harga lebih murah, mencegah sineresis dan berasal dari selulosa (non hewani) (Purwanto, 2006).

Penambahan penstabil perlu dibatasi namun juga disesuaikan dengan karakteristik yang akan dihasilkan, jika konsentrasi penstabil tidak sesuai maka akan menghasilkan es krim dengan struktur yang kasar dan mudah meleleh. Berdasarkan SNI-01-0222-1995 tentang bahan tambahan pangan golongan stabilizer, batas maksimum penggunaan karagenan dan CMC dalam produk es krim yaitu $10 \mathrm{~g} / \mathrm{kg}(\mathrm{b} / \mathrm{b})$. Oleh sebab itu, perlu dikaji mengenai penggunaan karagenan dan CMC dengan konsentrasi yang sesuai dalam pembuatan es krim edamame agar menghasilkan es krim dengan karakteristik yang baik dan iinginkan

\section{METODE PENELITIAN}

\section{Alat dan Bahan}

Peralatan yang digunakan dalam penelitian ini adalah neraca analitik, beaker glass $50 \mathrm{ml}$, baskom, blender merk Philips, saringan, spatula, gelas ukur 500 $\mathrm{ml}$, kompor, freezer, sendok, termometer, cup ice cream, ICM (Ice Cream Maker), colourreader minolta CR-10, penetrometer, penggaris. Bahan utama yang digunakan adalah edamame yang diperoleh dari pasar Tanjung Jember dan bahan pembantu meliputi air, gula kristal putih merk Gulaku, whipping cream (merk Haan), garam, keragenan dan CMC.

\section{Tahapan Penelitian}

\section{Pembuatan susu edamame}

Pembuatan susu edamame dimulai dari pencucian edamame untuk menghilangkan kotoran yang menempel pada edamame lalu dilakukan hot water blanching selama 3 menit dengan tujuan untuk inaktivasi enzim lipoksigenase yang menyebabkan bau langu pada edamame. Setelah itu dilakukan pengupasan yang bertujuan untuk memisahkan biji dan kulit edamame. Biji edamame yang telah dipisahkan dari kulitnya setelah itu dilakukan penimbangan sebanyak 100 gram. Setelah proses penimbangan kemudian dilakukan penghancuran menggunakan blender agar didapatkan bubur edamame halus dengan perbandingan air dan edamame $4: 1(\mathrm{v} / \mathrm{w})$. Edamame yang telah dihancurkan dan menjadi bubur disaring untuk memisahkan filtrat dan ampasnya. Filtrat atau susu edamame tersebut dilakukan proses pasteurisasi pada suhu $80^{\circ} \mathrm{C}$ selama 25 detik untuk membunuh mikroba patogen. Setelah suhu dan waktu pasteurisasi tercapai maka susu edamame diangkat dan didinginkan.

\section{Pembuatan es krim edamame}

Susu edamame sebanyak $350 \mathrm{ml}$ dilakukan pencampuran dengan bahan penstabil sesuai perlakuan (karagenan, CMC) konsentrasi masing-masing 0,2\%, $0,4 \%, 0,6 \%$ dari volume susu edamame. Campuran tersebut diaduk rata hingga penstabil larut dalam susu edamame. Setelah itu dilakukan pencampuran kembali dengan gula sebanyak $15 \%$ dan whipping cream 10\%. Proses selanjutnya yaitu pembuihan dan pendinginan selama 35 menit menggunakan Ice Cream Maker (ICM) tujuan dari proses ini yaitu untuk membentuk overrun. Setelah adonan es krim edamame terbentuk maka dilakukan proses pengerasan (hardening) dengan cara penyimpanan dalam suhu $-18^{\circ} \mathrm{C}$ selama 24 jam untuk pembentukan kristal es krim didalam freezer. 


\section{Rancangan Percobaan}

Rancangan percobaan pada penelitian ini menggunakan Rancangan Acak Lengkap (RAL) dengan dua faktor. Perlakuan diulang sebanyak tiga kali. Faktor pertama dalam penelitian ini adalah jenis penstabil (Karagenan, CMC) dan faktor kedua adalah jumlah bahan penstabil $(0,2 \% ; 0,4 \% ; 0,6 \%)$. Dari kedua faktor tersebut menghasilkan enam kombinasi yaitu A1B1, A1B2, A1B3, A2B1, A2B2, A2B3.

Data yang diperoleh dianalisis secara statistik dengan menggunakan uji sidik ragam (ANOVA) pada taraf signifikasi $\leq$ $5 \%$, apabila terdapat perbedaan dilanjutkan dengan uji DNMRT (Duncan New Multiple Range Test). Perlakuan terbaik ditentukan menggunakan uji efektivitas berdasarkan hasil pengujian sifat organoleptik yang meliputi kesukaan warna, aroma, rasa, tekstur, dan kesukaan keseluruhan (De Garmo et al., 1984).

\section{Metode Analisis}

Overrun (Goff and Hartel, 2013)

Pengukuran Overrun untuk mengetahui daya kembang es krim. Pengembangan volume es krim dinyatakan sebagai overrun dan dihitung berdasarkan perbedaan volume es krim dengan volume adonan mula-mula. Pengukuran overrun dilakukan dengan menimbang beaker glass $50 \mathrm{ml}$ untuk wadah adonan es krim. Lalu adonan sebelum proses pembuihan dimasukan kedalam beaker glass sebanyak $50 \mathrm{ml}$ dan ditimbang. Setelah proses pembuihan es krim dimasukan pada beaker glass sebanyak $50 \mathrm{ml}$. Overrun dapat dihitung dengan rumus sebagai berikut:

Overrun $=\frac{\text { berat adonan }- \text { berat adonan es krim }}{\text { berat adonan es krim }} \times 100 \%$

\section{Warna menggunakan color reader}

Pengukuran warna dilakukan dengan menempelkan ujung alat pada permukaan bahan yang diamati. Pengukuran dilakukan sebanyak lima kali ulangan pada daerah yang berbeda dan dirata-rata. Nilai L yang tertera pada layar colour reader yaitu tingkat kecerahan warna. Tingkat kecerahan diperoleh berdasarkan rumus:

$$
\mathrm{L}=\frac{\mathrm{L} \text { Standart }(94,35) \times \mathrm{L} \text { sampel }}{\mathrm{L} \text { Standar Keramik }(89,9)}
$$

Keterangan: Nilai kecerahan (L) berkisar antara $0-100$ yang menunjukkan warna hitam hingga putih.

Kecepatan meleleh (Elieste et al., 2010)

Es krim yang telah dibekukan diletakkan pada saringan. Kemudian diukur tingginya pada 5 titik yang berbeda. Es krim dibiarkan meleleh pada suhu ruang. Setiap interval waktu 15 menit selama 60 menit dilakukan pengukuran tinggi es krim pada titik-titik yang ditentukan.

Kecepatan meleleh $=100 \%-\left(\frac{\sum_{i=5}^{i} \mathrm{Ti}}{\text { To }} \times 100 \%\right)$

Keterangan :

$\sum_{i=1}^{i=5} T i=$ akumulasi es krim meleleh

To = tinggi es krim 15 menit sebelumnya

$\mathrm{n}=4$

\section{Tekstur}

Sampel diletakkan dibawah jarum penetrometer. Peletakan jarum yaitu pada permukaan sampel dan dilihat serta dicatat nilai awal yang ditunjukan oleh jarum yang ada pada skala setelah itu lepas pengait pengatur jarum selama 10 detik menggunakan stopwatch, jauhnya skala penanda dibaca bergeser dari angka nol dan dilihat nilainya pada skala. Hasil pengukuran tekstur sampel dapat dibaca pada skala dan dinyatakan dalam satuan $\mathrm{mm} / 10$ detik.

Uji sensoris (Setyaningsih et al., 2010)

Uji sensoris yang dilakukan meliputi kesukaan warna, aroma, rasa, tekstur, dan kesukaan keseluruhan. Cara pengujian 
dilakukan dengan uji hedonik atau kesukaan. Pada penilaian uji kesukaan, panelis yang berjumlah 25 orang diminta untuk memberikan kesan terhadap kesukaan warna, aroma, rasa, tekstur, dan kesukaan keseluruhan dari sampel dengan skala numerik sebagai berikut:

$$
\begin{array}{ll}
1= & \text { Sangat tidak suka } \\
2= & \text { Tidak suka } \\
3= & \text { Agak Tidak Suka } \\
4= & \text { Netral } \\
5= & \text { Agak Suka } \\
6= & \text { Suka } \\
7= & \text { Sangat Suka }
\end{array}
$$

\section{HASIL DAN PEMBAHASAN}

\section{Sifat Fisik Es Krim Edamame}

Overrun es krim

Faktor A (jenis penstabil) dan faktor B (konsentrasi penstabil) berpengaruh nyata terhadap overrun es krim edamame serta terdapat interaksi antara kedua faktor tersebut. Nilai rata-rata overrun es krim edamame berkisar antara $15,56 \%$ - 38,95\%. ). Notasi f pada perlakuan $\mathrm{CMC} 0,2 \%$ paling berpengaruh pada nilai overrun es krim edamame. Nilai overrun es krim edamame dapat dilihat pada Gambar 1.

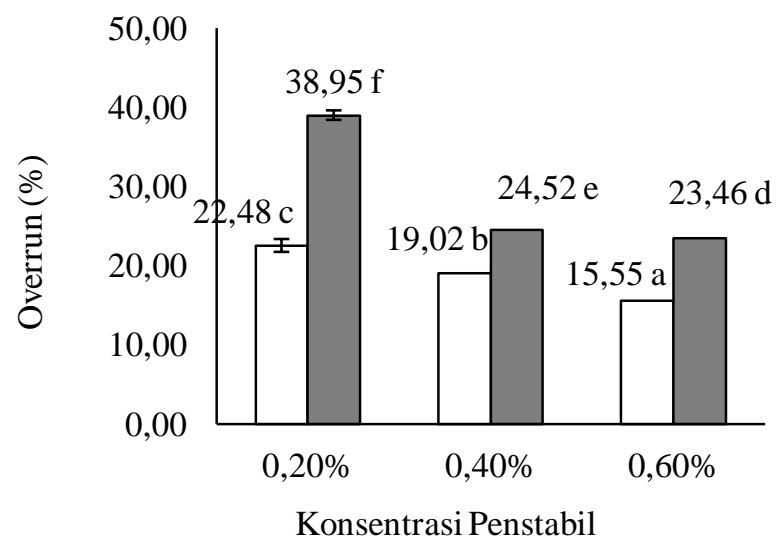

Gambar 1. Overrun es krim edamame dengan penstabil karagenan ( $\square$ ) dan CMC ( $\square$ )
Semakin tinggi nilai overrun maka es krim semakin baik. Overrun es krim biasanya antara 70-80\%, sedangkan untuk industri rumah tangga berkisar antara 3550\% ( Supriyanto et al., 2001). Notasi f pada perlakuan A2B1 (CMC 0,2\%) memiliki nilai overrun-nya paling tinggi dan berdasarkan aspek ekonomis jumlah penstabil yang digunakan lebih sedkit yaitu $0,2 \%$ dengan jumlah penstabil sekian maka dapat dipilih perlakuan tersebut yang terbaik untuk parameter overrun.

Overrun yang tinggi pada perlakuan A2B2 (notasi f) disebabkan karena kemampuan CMC dalam mengikat air lebih kecil dari pada Karagenan, Karagenan merupakan senyawa hidrokoloid yang terdiri atas ester kalium, natrium, magnesium dan kalium sulfat dengan galaktosa 3,6 anhidrogalaktosa kopolimer sedangkan CMC terdiri dari unit molekul sellulosa yang setiap unit anhidroglukosa memiliki tiga gugus hidroksil dan beberapa atom hidrogen dari gugus hidroksil tersebut disubstitusi oleh carboxymethyl. Karagenan terdiri atas sulfat yang bersifat hidrofilik sehingga mempengaruhi pada kekuatan pengikatan air pada adonan es krim. Interaksi karagenan dan air terjadi melalui ikatan elektrostatik yaitu air dengan muatan negatif grup sulfat dari molekul karagenan dan melalui ikatan hidrogen yaitu pada gugus hidroksil di sepanjang rantai karagenan (Gaonkar, 1995). Overrun juga dipengaruhi seberapa besar penambahan penstabil. Jumlah penstabil yang banyak mengakibatkan adonan mengental dan mengalami kesulitan untuk mengembang dan udara sukar menembus masuk permukaan adonan (Arbuckle, 1996).

\section{Kecerahan es krim}

Nilai kecerahan es krim yang diperoleh berkisar antara 78,74 sampai 80,45 . Nilai kecerahan es krim edamame dapat dilihat pada Gambar 2. 


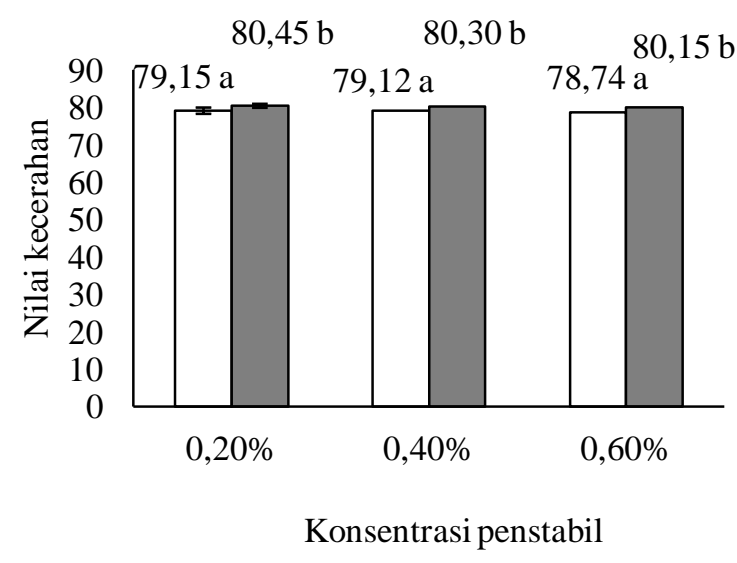

Gambar 2. Kecerahan es krim edamame dengan penstabil karagenan ( $\mathrm{\square})$ dan CMC ( $\square$ )

Faktor A (jenis penstabil) berpengaruh nyata terhadap warna es krim edamame dan faktor B (konsentrasi) tidak berpengaruh nyata terhadap warna es krim serta tidak terdapat interaksi antara kedua faktor tersebut.

Kecerahan es krim dipengaruhi oleh penstabil. Pada Gambar 2 terlihat bahwa notasi $b$ menghasilkan nilai kecerahan lebih tinggi dari pada notasi a. Hal tersebut menunjukkan bahwa notasi b yang paling berpengaruh dalam kecerahan es krim. Hasil kecerahan es krim berbanding lurus dengan nilai overrun. Jika overrun tinggi menghasilkan es krim semakin cerah.

\section{Kecepatan meleleh es krim edamame}

Nilai kecepatan meleleh es krim yang diperoleh dalam penelitian ini berkisar antara 12,5\%/15 menit sampai 51,5 \%/15 menit. Nilai semakin tinggi menunjukkan bahwa kecepatan meleleh es krim yang semakin besar. Kecepatan meleleh es krim dapat dilihat pada Gambar 3.

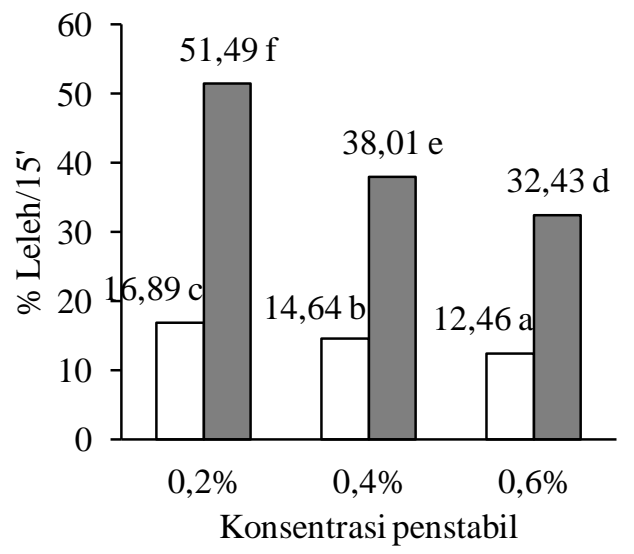

Gambar 3. Kecepatan meleleh es krim dengan penstabil karagenan $(\square)$ dan $\mathrm{CMC}(\square)$

Kecepatan meleleh es krim pada taraf nyata $\leq 5 \%$ menunjukkan bahwa faktor A (jenis penstabil) dan faktor B (konsentrasi) berpengaruh sangat nyata terhadap kecepatan meleleh es krim dan keduanya terdapat interaksi. Pada notasi $\mathrm{f}$ menghasilkan es krim dengan nilai kecepatan meleleh paling maksimal. Nilai kecepatan leleh es krim berbanding lurus dengan overrun. Semakin tinggi nilai overrun maka es krim yang dihasilkan akan lebih cepat meleleh (Suprayitno et al., 2001).

\section{Tekstur es krim edamame}

Tekstur es krim edamame pada taraf 5\% menunjukkan bahwa faktor $\mathrm{A}$ (jenis penstabil) dan faktor B (konsentrasi) berpengaruh nyata terhadap tekstur es krim edamame dan terdapat interaksi pada kedua faktor perlakuan tekstur es krim edamame. Rata-rata nilai tekstur edamame berkisar antara $6,67 \mathrm{~mm} / 10$ detik sampai $13,13 \mathrm{~mm} / 10$ detik. Nilai tekstur es krim edamame dapat dilihat pada Gambar 4. 


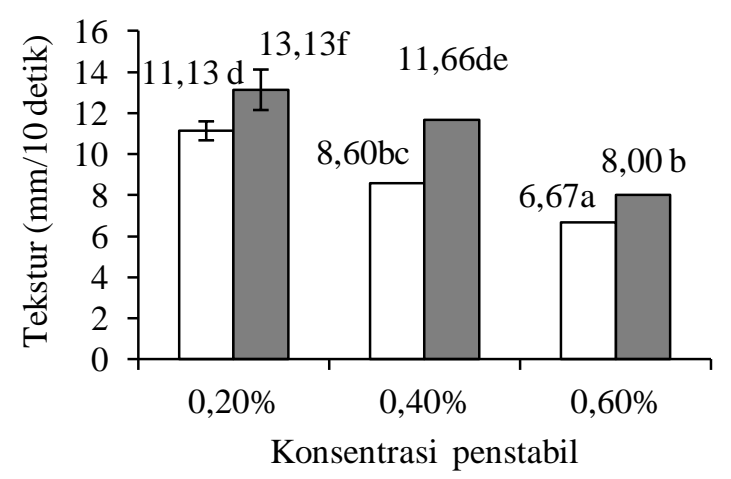

Gambar 4. Tekstur edamame dengan penstabil karagenan ( $\square)$ dan CMC ( $\square)$

Pada Gambar 4 menunjukkan bahwa semakin menurunnya nilai tekstur es krim maka menunjukkan bahwa es krim tersebut lunak. Tekstur es krim edamame berbanding lurus dengan overrun es krim. Semakin tinggi overrun maka semakin lunak tekstur yang dihasilkan (Clarke, 2004).

\section{Sifat Organoleptik Es Krim Edamame Warna}

Nilai kesukaan warna es krim edamame berkisar antara 4,08 sampai 6,36 (netral sampai suka). Berdasarkan uji sidik ragam pada taraf 5\% menunjukkan bahwa jenis dan konsentrasi penstabil es krim edamame berbeda nyata. Hasil uji kesukaan warna es krim edamame dapat dilihat pada Gambar 5.

Nilai kesukaan tertinggi terdapat pada es krim edamame dengan penstabil karagenan $0,4 \%$. Pada pengamatan fisik kecerahan es krim edamame yang diukur menggunakan color reader, es krim edamame dengan penstabil karagenan 0,4\% memiliki kecerahan sebesar 79,12. Hal tersebut menunjukkan bahwa panelis menyukai es krim edamame yang cerah dengan nilai kecerahan 79,12.

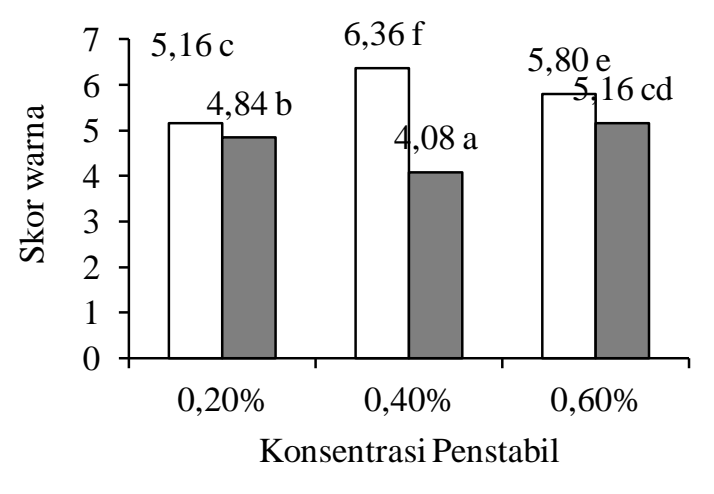

Gambar 5. Skor uji kesukaan warna es krim edamame dengan penstabil karagenan ( $\square)$ dan CMC ( $\square)$

\section{Aroma}

Nilai kesukaan aroma dari es krim edamame berkisar antara 3,92 hingga 4,6 (agak tidak suka sampai netral). Berdasarkan hasil uji sidik ragam pada taraf 5\% menunjukan bahwa jenis dan konsentrasi bahan penstabil tidak berpengaruh nyata terhadap kesukaan aroma es krim edamame. Hal tersebut membuktikan bahwa karagenan dan CMC serta perbedaan konsentrasi tidak memberikan pengaruh terhadap kesukaan aroma es krim edamame (Glicksman et al., 1984). Es krim merupakan jenis makanan beku sehingga intensitas aroma yang dihasilkan tidak terlalu tinggi pada saat baru dikeluarkan dari freezer (Webb, 1981). Hasil uji kesukaan aroma es krim edamame dapat dilihat pada Gambar 6. 


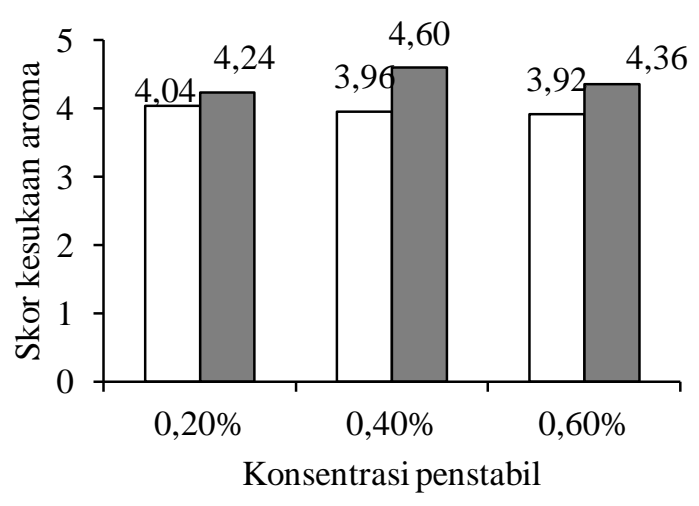

Gambar 6. Skor uji kesukaan aroma es krim edamame dengan penstabil karagenan ( $\square$ ) dan CMC ( $\square$ )

\section{Rasa}

Nilai kesukaan rasa dari es krim edamame berkisar antara 5,84-6,04. Hal ini menunjukkan bahwa panelis menerima rasa dari es krim edamame dengan rentang agak suka hingga suka. Dari hasil uji sidik ragam pada taraf 5\% menunjukkan bahwa jenis dan konsentrasi penstabil tidak berpengaruh nyata terhadap kesukaan rasa es krim edamame. Menurut Prasetyo (2013) penstabil tidak mempengaruhi rasa es krim karena CMC dan karagenan merupakan zat yang tidak berasa dan berbau. Hasil uji kesukaan rasa dari es krim edamame dapat dilihat pada Gambar 7.

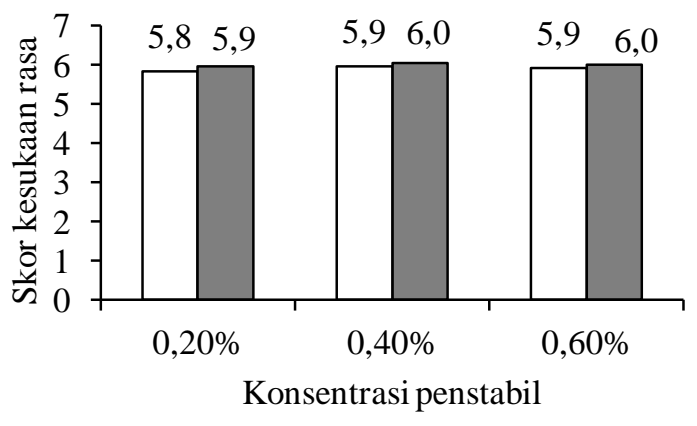

Gambar 7. Skor uji kesukaan rasa es krim edamame dengan penstabil karagenan $(\square)$ dan CMC ( $\square)$

\section{Tekstur}

Nilai untuk parameter berkisar antara 5,2 hingga 6,2 (agak suka sampai suka). Hasil uji kesukaan tekstur es krim edamame dapat dilihat pada Gambar 8.

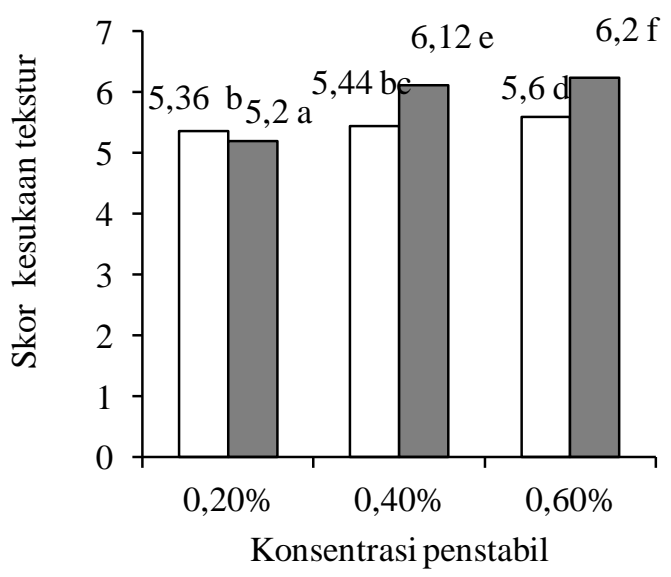

Gambar 8. Skor uji kesukaan tekstur es krim edamame dengan penstabil karagenan $(\square)$ dan CMC ( $\square)$

Jenis dan konsentrasi bahan penstabil berpengaruh nyata terhadap es krim edamame. Nilai kesukaan tertinggi terdapat pada CMC 0,6\%. Berdasarkan sifat fisik tekstur es krim dengan penstabil CMC 0,6\% (A2B3) yaitu sebesar 8,0 $\mathrm{mm} / 10$ detik. Hal tersebut menunjukkan bahwa panelis menyukai es krim dengan tekstur tridak terlalu lunak dan tidak terlalu keras.

\section{Keseluruhan \\ Nilai keseluruhan merupakan nilai yang menunjukan kesukaan panelis terhadap keseluruhan parameter warna, aroma, tekstur dan rasa. Nilai rata-rata keseluruhan es krim edamame berkisar antara 4,6-5,8. Hal tersebut menunjukkan bahwa rentang nilai kesukaan panelis yaitu agak suka hingga suka.}




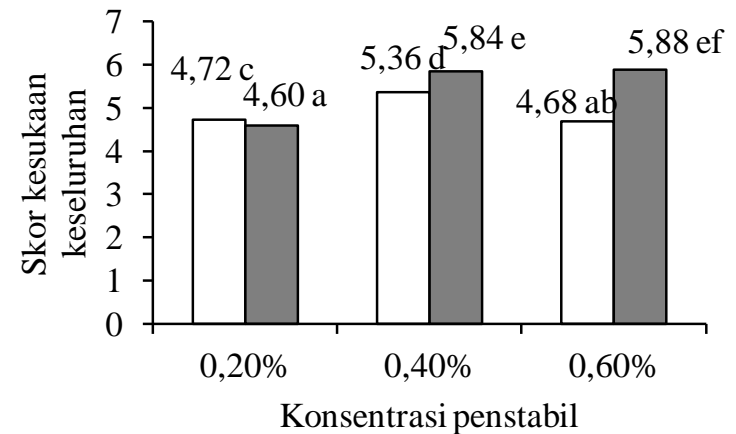

Gambar 9. Uji kesukaan keseluruhan es krim edamame dengan penstabil karagenan ( $\square)$ dan CMC ( $\square)$

Hasil uji sidik ragam pada taraf 5\% terhadap kesukaan keseluruhan es krim edamame menunjukkan bahwa jenis dan konsentrasi bahan penstabil berpengaruh nyata terhadap nilai keseluruhan es krim edamame. Hasil uji keseukaan keseluruhan es krim edamame dapat dilihat pada Gambar 9.

Nilai tertinggi dari kesukaan keseluruhan es krim edamame berada pada es krim dengan penstabil CMC 0,6\%, namun tidak berbeda nyata pada es krim dengan penstabil CMC $0,4 \%$ dan nilai terendah terdapat pada es krim dengan penstabil karagenan 0,6\%. Pada hasil yang didapatkan maka nilai kesukaan keseluruhan es krim edamame lebih ditentukan oleh kesukaan tekstur dengan nilai 6,24 (suka sampai sangat suka) dan rasa dengan nilai 6 (suka).

\section{Es Krim Edamame Terbaik}

Hasil uji efektivitas menunjukkan bahwa perlakuan terbaik terdapat pada es krim dengan jenis penstabil CMC konsentrasi $0,4 \%$. Nilai overrun $24,52 \%$, nilai kesukaan warna 4,08 (netral sampaiagak suka), nilai kesukaan aroma 4,60 (netral sampai agak suka), nilai kesukaan ras4 6,05 (suka-sangat suka), nilai nilai kesukaan tekstur 6,12 (suka sampai sangat suka), kesukaan keseluruhan 5,84 (agak suka sampai suka).
Hasil uji efektivitas es krim edamame dapat dilihat pada Tabel 1.

Tabel 1. Hasil uji efektivitas es krim edamame

\begin{tabular}{lcc}
\hline Jenis & Konsentrasi & $\begin{array}{c}\text { Nilai } \\
\text { Efektivitas }\end{array}$ \\
\hline Karagenan & $0,2 \%$ & 0,256 \\
& $0,4 \%$ & 0,464 \\
CMC & $0,6 \%$ & 0,523 \\
& $0,2 \%$ & 0,479 \\
& $0,4 \%$ & 0,734 \\
& $0,6 \%$ & 0,733 \\
\hline
\end{tabular}

\section{KESIMPULAN}

Es krim terbaik pada es krim edamame dengan penstabil CMC pada konsentrasi $0,4 \%$ yang mempunyai overrun 24,51\%, nilai kecerahan 80,30, kecepatan leleh $38,01 \% / 15$ menit, tekstur $11,7 \mathrm{~mm} / 10$ detik dan nilai kesukaan warna 4,08 (netral sampaiagak suka), nilai kesukaan aroma 4,60 (netral sampai agak suka), nilai kesukaan rasa 6,05 (sukasangat suka), nilai nilai kesukaan tekstur 6,12 (suka sampai sangat suka), kesukaan keseluruhan 5,84 (agak suka sampai suka).

\section{DAFTAR PUSTAKA}

Arbuckle W. S. 1996. Ice Cream. The AVI Publishing Company. Westport, Connecticut.

Clarke, C. 2004. The Science of Ice Cream. The Royal Society of Chemistry, Thomas Graham House. Milton Road, Cambridge (UK).

Darma, G. S., Diana P., Endang N. 2013. Pembuatan es krim jagung manis kaji an jenis zat penstabil, konsentrasi non dairy cream serta aspek kelayakan finansial. Jurnal REKA Industri Media Teknologi dan Menejemen Agroindustri, 1 (1).

De Garmo, E.P., Sullevan, W.E dan Canana, C.R. 1984. Engineering Economy $7^{\text {th }}$. Macmilan Publishing co. Inc., New York. 
Elieste, Silva, J., Suzana, C., Silva, L. 2010. Effect of different sweetener blends and fat types on ice cream properties. Journal food science and technology, ISSN 0101-2061.

Gaonkar, A. G. 1995. Addition of Hydrocolloids and Non-muscle Proteins to Sardine (Sardina pilchardus) mince gels; Effects of Salt Concentration. Food Chemistry, 56 (4).

Glicksman, M. 1983. Food Hydrocolloids, Volume II. CRC Press Inc., New York.

Goff, H. D., Hartel, R. W. 2013. Ice Cream. Edisi 7. Springer, New York.

Khaeruni, R., Andi, Budi, T., Antonius, S., Meity, S. S. 2008. Virulensi sejumlah isolat Xanthomonas axonopodis $P V$ Glycines asal edamame pada tiga varietas kedelai. Jurnal HPT Tropika, 8 (1).

Kurniasanti, S. A., Sumarwan, U., Kurniawan, B. P. Y. 2014. Analisis dan Model Strategi Peningkatan Daya Saing Produk Edamame Beku. Jurnal Manajemen and Agribisnis, 11 (1).

Muaris, Hindah. 2013. Khasiat Edamame untuk Kestabilan Kesehatan. Kompas Gramedia, Jakarta.

Prasetyo, D. 2013. "Pengaruh Penambahan dan Lama Blanching Sari Kedelai (Glycine max) terhadap Sifat Fisik, Kimia, serta Organoleptik Es Krim Ubi Jalar Kuning (Ipomea batatas L)". Skripsi. Universitas Brawijaya, Malang.

Purwanto, A. 2006. "Pengaruh Jenis Penstabil dan Konsentrasi Shortening Terhadap Kualitas Es Krim Ubi Jalar Ungu Jepang". Skripsi. Universitas Brawijaya, Malang.

Setyaningsih, D., Apriyantono, A., Sari, M. P. 2010. Analisis Sensori untuk Industri Pangan dan Agro. IPB Press, Bogor.

Suprayitno, E., Kartikaningsih dan Rahayu. 2001. Pembuatan es krim menggunakan dtabilisator natrium alginat dari Surgassum sp.. Jurnal Makanan Tradisional Indonesia, 1(3): 23-27.
Susrini. 2003. Pengantar Teknologi Pengolahan Susu. Fakultas Peternakan Universitas Bawijaya, Malang.

Webb, B. H., Arbuckle W. S. 1977. Freezing of Dairy Producs. Di dalam: Desrosier, N. W., Tresser D. K. editor. Fundamentals of Food Freezing. The AVI Publishing Company, Inc. Westport, Connecticut.

Yordanio, J., Pudjo, D., Bambang, E. 2015. Analisis Pengendalian Kualitas Frozen Edamame Dengan Menggunakan Statistical Process Control (SPC) Pada PT Mitratani Dua Tujuh. Artikel Ilmiah. Universitas Jember. 